\title{
INVESTIGATION OF THE NEED FOR PHYSICAL TREATMENT DURING PROLONGED ABSENCE FROM WORK
}

\author{
BY \\ C. R. LOWE and THOMAS McKEOWN \\ From the Department of Social Medicine, University of Birmingham
}

In 1949 a Ministry of Health circular [R.H.B. (49)36] attempted to define the responsibility of the National Health Service in relation to prevention and limitation of disability. It was stated that:

the Ministry of Labour's Resettlement Services... . deal with the terminal disability arising from earlier sickness or injury, and do not begin until disability is established.

and that the Health Service should make adequate provision prior to that stage, in order to reduce

the large number of patients whose prolonged and illdirected convalescence. ... . causes so much absenteeism and often sows the seeds of a permanent disability neurosis.

For this purpose the circular suggested that hospital rehabilitation services should be expanded, and should include physiotherapy departments, remedial gymnasia, and occupational therapy rooms.

Responsibility for these services falls mainly upon Regional Hospital Boards. The Boards are, however, finding it difficult to finance expansion of the traditional services, and require to know whether the cost of extending the rehabilitation services will be justified. According to the Ministry circular, experience has shown that:

early measures of rehabilitation, combined with expert guidance through convalescence, produce striking results in the recovery of fitness, the reduction of permanent disability, and the shortening of time off work.

No evidence is quoted in support of this statement, and no estimate is given of the cost of the services, or of the extent of the expansion required.

The present investigation was undertaken to provide information on some of these matters for the guidance of the Birmingham Regional Hospital Board. We have attempted to assess the incidence of prolonged absence from work, and have enquired with only partial success, to what extent expansion of rehabilitation services might be expected to contribute to the welfare of patients and to reduction of the period of absence.

\section{MATERIAL}

As it was not our purpose to explore absenteeism in general, upon which there is already a considerable literature, we confined our attention to the two groups most likely to benefit from physical treatment:

(a) patients admitted to hospital,

(b) patients not admitted to hospital but who were absent from work for a considerable period.

The two groups were readily identified by taking all patients absent 28 days or more, since a small preliminary enquiry had indicated that employees absent for less than a month had rarely been in hospital, and that very few of them required physical treatment which they had not received.

The enquiry was conducted through the works' medical officers of six large firms (the smallest had more than 2,000 employees), which together employed 20,677 men (6) and 9,809 women. These firms were engaged in both light and heavy industry, and provided a wide variety of occupations. The medical officers interviewed on return to work all absentees who had left work because of illness or accident between October 1, 1950, and September 30, 1951, and had been absent for 28 or more consecutive days. A record card completed for each absentee covered the following principal points:

(a) duration of absence (divided, for patients admitted to hospital, into periods before admission, in hospital, and after discharge);

(b) medical cause of absence as indicated by general practitioner's certificate and patient's statement;

(c) identification by the medical officers of patients considered to have required out-patient physical treatment or admission to a convalescent home during their absence, with details of services actually received.

Since the enquiry was restricted to firms with a welldeveloped medical service, results are to some extent unrepresentative. Five of the six firms provide infra-red and ultra-violet light treatment (at one firm massage, wax baths, and a full range of galvanic, faradic, and sinusoidal therapy are available) and two have their own convalescent homes; it is therefore probable that the need for these services is greater than the results suggest. Moreover there is reason to believe that the incidence of prolonged absence was underestimated, first because 
some absentees who returned to work were undoubtedly missed, and second, because no allowance was made for workers who had not returned 6 months after the completion of the enquiry.

\section{InCidence of Prolonged Absence}

Of the 30,486 employees, $5 \cdot 2$ per cent. $(1,576)$ left work during the year, because of sickness or accident, and were absent for 28 or more consecutive days; 1.4 per cent. (427) had been admitted to hospital. As indicated above, the incidence of prolonged absence was somewhat higher than these figures suggest; in one firm 9.8 per cent. of the employees were absent for at least a month, and 2.9 per cent. had been admitted to hospital.

The mean duration of absence was 66 days for all absentees, and 83 and 60 days for persons admitted and not admitted to hospital respectively. The difference between the means for the two sexes was trivial.

Table I gives the percentage distribution of absentees according to duration of absence. Two in every five employees admitted to hospital were away from work for 3 months or more, and the

TABLE I*

PERCENTAGE DISTRIBUTION OF ABSENTEES ACCORDING TO DURATION OF ABSENCE

\begin{tabular}{|c|c|c|c|c|c|}
\hline \multirow{2}{*}{ Patients } & \multicolumn{5}{|c|}{ Duration of Absence (wks) } \\
\hline & 4 & 8- & $12-$ & $\begin{array}{c}16 \\
\text { and } \\
\text { over }\end{array}$ & Total \\
\hline Admitted to hospital & $32 \cdot 6$ & $27 \cdot 4$ & $18 \cdot 7$ & $21 \cdot 3$ & $\begin{array}{c}\text { (427) } \\
100 \text { per cent. }\end{array}$ \\
\hline $\begin{array}{ccc}\text { Not admitted } & \text { to } \\
\text { hospital } & \ldots & \ldots\end{array}$ & $60 \cdot 6$ & $23 \cdot 4$ & $9 \cdot 7$ & $6 \cdot 3$ & $\begin{array}{c}(1,149) \\
100 \text { per cent. }\end{array}$ \\
\hline
\end{tabular}

Numbers of absentees are given in brackets.

* With the exception of Table II, the Tables are based on the experience of 30,486 employees $(20,677$ males and 9,809 females).

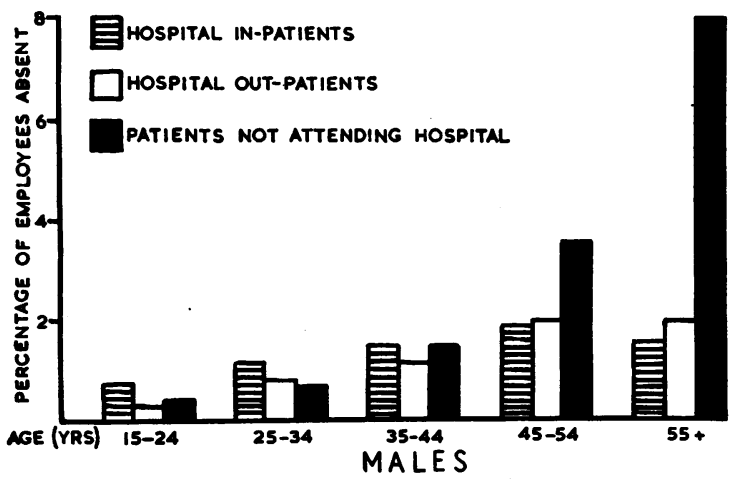

incidence of prolonged absence was also quite high among persons not admitted to hospital.

Table II explores the association between absenteeism and age; not all firms were able to give the age distribution of their employees and the data are derived from the experience of 11,484 men and 7,910 women. The incidence of prolonged absence rises rapidly with age; this is mainly due to the association between incidence and age in patients not admitted to hospital, and more particularly in patients not attending hospital out-patient departments (see Figure, below).

TABLE II

PERCENTAGE OF EMPLOYEES ABSENT, BY AGE AND SEX

\begin{tabular}{|c|c|c|c|c|c|c|}
\hline \multirow{2}{*}{ Sex } & \multicolumn{6}{|c|}{ Age (yrs) } \\
\hline & $15-$ & $25-$ & $35-$ & 45- & $\begin{array}{c}55 \text { and } \\
\text { over }\end{array}$ & $\begin{array}{c}\text { All } \\
\text { Ages }\end{array}$ \\
\hline Male .. & $\begin{array}{l}1.4 \\
(22)\end{array}$ & $\begin{array}{l}2 \cdot 7 \\
(69)\end{array}$ & $\begin{array}{r}4 \cdot 2 \\
(112)\end{array}$ & $\begin{array}{r}7 \cdot 5 \\
(188)\end{array}$ & $\begin{array}{l}11 \cdot 6 \\
(245)\end{array}$ & $\begin{array}{r}5 \cdot 5 \\
(636)\end{array}$ \\
\hline Female & $\begin{array}{l}1.9 \\
(52)\end{array}$ & $\begin{array}{l}3 \cdot 5 \\
(69)\end{array}$ & $\begin{array}{c}5 \cdot 1 \\
(82)\end{array}$ & $\begin{array}{l}7 \cdot 1 \\
(93)\end{array}$ & $\begin{array}{l}6 \cdot 5 \\
(25)\end{array}$ & $\begin{array}{r}4 \cdot 0 \\
(321)\end{array}$ \\
\hline
\end{tabular}

This Table is based on the experience of 11,484 male and 7,910 female employees of known age.

Assessment of Patients' Need for Physical Treatment AND CONVAlEsCenCe

As stated above, the works' medical officers recorded details of physical treatment received by patients not admitted to hospital, and by hospital patients after discharge; they attempted to assess whether patients who had not received physical treatment would have benefited from it, and Table III (overleaf) shows their findings. Some form of physical therapy had been received by 8.7 per cent. of patients, and it was considered that a further $7 \cdot 3$ per cent. would have benefited from treatment but had not received it. The services appear to be reasonably adequate for patients discharged from hospital, but it was considered that 9 per cent. (103) of the patients not admitted to hospital might have benefited from treatment

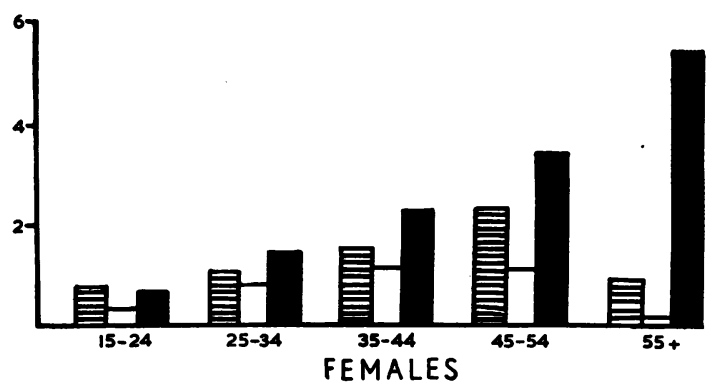

FIGURE.-Incidence of absenteeism distributed by age and sex, and by type of hospital treatment received. 
TABLE III

PATIENTS CONSIDERED TO HAVE REQUIRED OUT-PATIENT PHYSICAL TREATMENT

\begin{tabular}{|c|c|c|c|c|}
\hline \multirow{3}{*}{ Patients } & \multicolumn{3}{|c|}{ Physical Treatment } & \multirow{3}{*}{ Total } \\
\hline & \multicolumn{2}{|c|}{ Considered Necessary } & \multirow{2}{*}{$\begin{array}{c}\text { Considered } \\
\text { Unnecessary }\end{array}$} & \\
\hline & Received & $\begin{array}{c}\text { Not } \\
\text { Received }\end{array}$ & & \\
\hline $\begin{array}{cc}\text { Admitted } & \text { to } \\
\text { hospital } & .\end{array}$ & $\begin{array}{l}14 \cdot 1 \\
(60)\end{array}$ & $\begin{array}{l}2 \cdot 8 \\
(12)\end{array}$ & $\begin{array}{l}83 \cdot 1 \\
(355)\end{array}$ & $\begin{array}{l}100 \text { per cent. } \\
(427)\end{array}$ \\
\hline $\begin{array}{l}\text { Not admitted } \\
\text { to hospital }\end{array}$ & $\begin{array}{l}6 \cdot 7 \\
(77)\end{array}$ & $\begin{array}{r}9 \cdot 0 \\
(103)\end{array}$ & $\begin{array}{l}84 \cdot 3 \\
(969)\end{array}$ & $\begin{array}{l}100 \text { per cent. } \\
(1,149)\end{array}$ \\
\hline Total ... & $\begin{array}{r}8 \cdot 7 \\
(137)\end{array}$ & $\begin{array}{r}7 \cdot 3 \\
(115)\end{array}$ & $\begin{array}{r}84 \cdot 0 \\
(1,324)\end{array}$ & $\begin{array}{l}100 \text { per cent } \\
(1,576)\end{array}$ \\
\hline
\end{tabular}

which they had not received. Table IV gives the diagnosis in these cases, most of which are of a kind usually considered suitable for physical therapy.

TABLE IV

DIAGNOSIS IN PATIENTS WHO MIGHT HAVE BENEFITED FROM OUT-PATIENT PHYSICAL TREATMENT BUT DID NOT RECEIVE IT

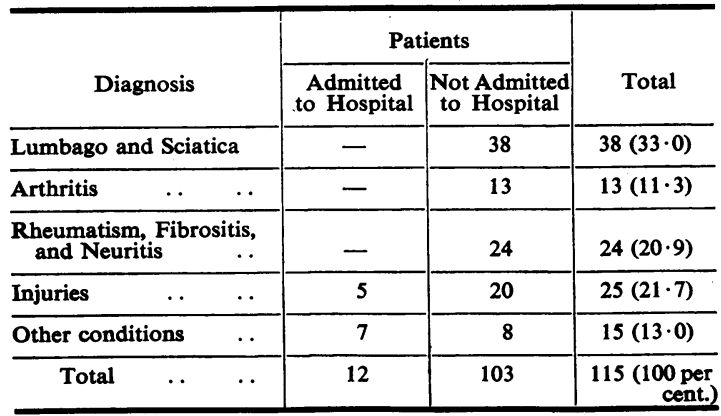

The medical officers considered that about onethird (510) of the absentees should have been sent to convalescent homes; less than one-sixth (229) had in fact been admitted (Table V).

TABLE V

PATIENTS CONSIDERED TO HAVE REQUIRED ADMISSION

\begin{tabular}{|c|c|c|c|c|}
\hline \multirow{3}{*}{ Patients } & \multicolumn{3}{|c|}{ Convalescent Home } & \multirow{3}{*}{ Total } \\
\hline & \multicolumn{2}{|c|}{ Considered Necessary } & \multirow{2}{*}{$\begin{array}{l}\text { Considered } \\
\text { Unnecessary }\end{array}$} & \\
\hline & Admitted & $\begin{array}{c}\text { Not } \\
\text { Admitted }\end{array}$ & & \\
\hline $\begin{array}{l}\text { Admitted to } \\
\text { hospital ... }\end{array}$ & $\begin{array}{l}27 \cdot 2 \\
(116)\end{array}$ & $\begin{array}{r}18 \cdot 3 \\
(78)\end{array}$ & $\begin{array}{l}54 \cdot 6 \\
(233)\end{array}$ & $\begin{array}{l}100 \text { per cent. } \\
\text { (427) }\end{array}$ \\
\hline $\begin{array}{l}\text { Not admitted } \\
\text { to hospital }\end{array}$ & $\begin{array}{r}9 \cdot 8 \\
(113)\end{array}$ & $\begin{array}{l}17 \cdot 7 \\
(203)\end{array}$ & $\begin{array}{l}72 \cdot 5 \\
(833)\end{array}$ & $\begin{array}{c}100 \text { per cent. } \\
(1,149)\end{array}$ \\
\hline Total .. & $\begin{array}{l}14 \cdot 5 \\
(229)\end{array}$ & $\begin{array}{l}17 \cdot 8 \\
(281)\end{array}$ & $\begin{array}{c}67 \cdot 6 \\
(1,066)\end{array}$ & $\begin{array}{c}100 \text { per cent. } \\
(1,576)\end{array}$ \\
\hline
\end{tabular}

The need is not confined to those who had not been in hospital, and 18 per cent. of hospital in-patients were thought to require a period of convalescence which had not been arranged. Table VI shows the type of patient who might have benefited from convalescence: about two-thirds of the hospital patients were recovering from operations and more than half of those not admitted to hospital had respiratory diseases.

TABLE VI

DIAGNOSIS IN PATIENTS WHO MIGHT HAVE BENEFITED FROM ADMISSION TO A CONVALESCENT HOME BUT WERE NOT ADMITTED

\begin{tabular}{|c|c|c|c|c|c|}
\hline \multirow{2}{*}{\multicolumn{3}{|c|}{ Diagnosis }} & \multicolumn{2}{|c|}{ Patients } & \multirow[b]{2}{*}{ Total } \\
\hline & & & \multirow{2}{*}{$\begin{array}{c}\begin{array}{c}\text { Admitted } \\
\text { to Hospital }\end{array} \\
-\end{array}$} & \multirow{2}{*}{\begin{tabular}{|c|}
$\begin{array}{c}\text { Not Admitted } \\
\text { to Hospital }\end{array}$ \\
48 \\
\end{tabular}} & \\
\hline $\begin{array}{c}\text { Bronchitis } \\
\text { chronic) }\end{array}$ & $\begin{array}{c}\text { acute } \\
\ldots\end{array}$ & $\begin{array}{c}\text { and } \\
\ldots\end{array}$ & & & $48(17 \cdot 1)$ \\
\hline Pneumonia & . & .. & 8 & 26 & $34(12 \cdot 1)$ \\
\hline Influenza & . & .. & - & 38 & $38(13 \cdot 5)$ \\
\hline Peptic ulcer & $\ldots$ & .. & 6 & 17 & $23(8 \cdot 2)$ \\
\hline \multicolumn{3}{|c|}{ Post-operative debility } & 48 & - & $48(17 \cdot 1)$ \\
\hline \multicolumn{2}{|c|}{ General debility } & .. & - & 20 & $20(7 \cdot 1)$ \\
\hline \multicolumn{2}{|c|}{ Other conditions } & $\ldots$ & 16 & 54 & $70(24 \cdot 9)$ \\
\hline Total & $\ldots$ & .. & 78 & 203 & $\begin{array}{r}281 \text { (100 per } \\
\text { cent.) }\end{array}$ \\
\hline
\end{tabular}

\section{EFFECT OF IMPRoved SeRvices on the DURATION OF} ABSENCE

We now enquire to what extent improved rehabili tation services may reduce the period of absence.

(a) Patients Admited to Hospital.-For patients admitted to hospital the period of absence can be divided into periods before admission, in hospital, and after discharge. The mean durations of these intervals are 8,21, and 54 days respectively. We are here concerned mainly with the periods before admission and after discharge; but it may be noted that 21 days is a little longer than the mean duration of stay usually quoted for general hospitals. This is partly because several patients were admitted to hospital more than once during their period of absence, and the mean is based on the total time spent in hospital by each patient, and partly because some were admitted to sanatoria and mental hospitals, in which mean duration of stay is much longer than in general hospitals.

(i) Interval between leaving work and entering hospital.-The mean interval between leaving work and entering hospital (8 days) may seem unduly long. The mean is misleading; more than half (243) of the 427 hospital patients were admitted within 48 hours of leaving work. Of the 92 patients who were at home a week or more before admission to hospital, 23 were admitted as medical or surgical emergencies arising in the course of a domiciliary 
illness and there is therefore no reason to believe that the interval could have been reduced. The remaining 69 patients had been waiting at home on the average 35 days for admission, 39 of them for surgical treatment, and 30 for medical investigation or treatment. While some of this delay may be attributable to the failure of general practitioners to refer patients quickly to hospital, it seems certain that it is due mainly to the difficulty of obtaining early admission for illnesses other than emergencies. Expansion of the rehabilitation services cannot of course be expected to have any effect on this interval, but in determining priority of admission hospitals might well consider not only the medical needs of the patient, but also whether it will be necessary for him to leave work while awaiting admission.

(ii) Interval between hospital discharge and return to work.-As noted above, the mean interval between hospital discharge and return to work was 54 days, and Table VII gives the distribution of patients according to the length of this interval. Only about one-fifth were at work within 4 weeks; two-fifths were away for 8 weeks or more.

TABLE VII

INTERVAL BETWEEN DISCHARGE FROM HOSPITAL AND RETURN TO WORK

\begin{tabular}{|c|c|c|c|c|c|}
\hline \multirow[b]{2}{*}{$\begin{array}{l}\text { Patients Admitted } \\
\text { to Hospital }\end{array}$} & \multicolumn{5}{|c|}{ Interval (wks) } \\
\hline & 0 & 4 & $8-$ & $\begin{array}{l}12 \\
\text { and } \\
\text { over }\end{array}$ & Total \\
\hline Number ... & 93 & 169 & 102 & 63 & 427 \\
\hline Percentage & $21 \cdot 8$ & $39 \cdot 6$ & $23 \cdot 9$ & $14 \cdot 8$ & 100 \\
\hline
\end{tabular}

To decide whether the period of post-hospital absence could be reduced by improved rehabilitation services, we must relate the interval to diagnosis and treatment. Unfortunately this can be done on reasonable numbers only in the case of patients submitted to certain operations. Table VIII shows that there are substantial differences in the interval,

(a) according to the nature of the operation (as would be expected),

(b) between persons of the same sex submitted to the same operation.

In an attempt to find an explanation for very prolonged absences we examined the records of the 26 patients entered in Table VIII who were away from work 10 weeks or more after leaving hospital. At least seventeen of them had medical reasons for absence of a kind unlikely to be much affected by physical treatment*. For the remaining nine patients

\footnotetext{
* For example a man past retiring age, absent 143 days after herniotomy, and a woman aged 51, absent 142 days after hysterectomy, both developed post-operative broncho-pneumonia; another woman who lost 116 days had a coronary thrombosis during convalescence after appendicectomy; the patient with the longest period of posthospital absence (215 days) developed septicaemia after haemorrhoidectomy.
}

information was incomplete, but in the opinion of the medical officers none would have benefited from physical treatment.

TABLE VIII

DISTRIBUTION OF PATIENTS ACCORDING TO INTERVAL BETWEEN DISCHARGE FROM HOSPITAL AND RETURN TO WORK

\begin{tabular}{|c|c|c|c|c|c|c|c|c|c|}
\hline \multirow[b]{2}{*}{ Operation } & \multicolumn{9}{|c|}{ Interval (wks) } \\
\hline & $2-$ & 4 & $6-$ & $8-$ & 10 & $12-$ & 14 & $\begin{array}{c}16 \text { and } \\
\text { over }\end{array}$ & Total \\
\hline $\begin{array}{c}\text { Herniotomy } \\
\text { (males) }\end{array}$ & 2 & 15 & 8 & 5 & 5 & - & - & 1 & 36 \\
\hline $\begin{array}{l}\text { Partial gastrec- } \\
\text { tomy (males) }\end{array}$ & - & 4 & 2 & 3 & 1 & 1 & - & 1 & 12 \\
\hline $\begin{array}{c}\text { Hysterectomy } \\
\text { (females) } . .\end{array}$ & - & 1 & - & 2 & 7 & - & 2 & 3 & 15 \\
\hline $\begin{array}{l}\text { Acute appen- } \\
\text { dicectomy } \\
\text { (both sexes) }\end{array}$ & 12 & 10 & 6 & 4 & 1 & 2 & - & 1 & 36 \\
\hline $\begin{array}{l}\text { Haemorrhoid- } \\
\text { ectomy (both } \\
\text { sexes) } \quad .\end{array}$ & 3 & 3 & 1 & 1 & - & - & - & 1 & 9 \\
\hline
\end{tabular}

The cases examined do not therefore suggest that improved physical treatment would have contributed materially to reduction of the duration of post-hospital absence. This is consistent with the assessment made by the medical officers, who considered that only $2 \cdot 8$ per cent. (12) of hospital patients might have benefited during convalescence from physical treatment which they had not received (Table III).

(b) Patients Not Admitted to Hospital.-We are unable to come to any firm conclusion about the probable effect of improved physical treatment on the duration of absence in patients not admitted to hospital. It will be recalled that it is for this group that existing services appear to be most deficient (Table III). Of the 1,149 patients, 103 might have benefited from treatment, but there are two reasons, neither of them conclusive, for doubting whether this treatment would have appreciably shortened the time lost from work:

(a) of the 184 patients absent 12 weeks or more, the proportion requiring, but not receiving, treatment ( 8 per cent.) was about the same as the proportion of the 965 absent less than 12 weeks ( 9 per cent.);

(b) among the patients absent 12 weeks or more who were considered to require physical treatment, there was no substantial difference between the treated and the untreated (125 and 124 days respectively) in mean duration of absence.

\section{Discussion}

It has been shown that the incidence of prolonged absence from work because of sickness or accident is 
high both among patients admitted and among those not admitted to hospital. According to the assessment of the works' medical officers, 7 per cent. of those absent more than a month would have benefited from physical treatment which they had not received, the need being most conspicuous among patients not admitted to hospital.

Although additional rehabilitation services would undoubtedly contribute to the welfare of some patients, the data do not suggest that they would have much effect upon the mean duration of absence. So far as we can judge this is determined mainly by medical conditions unlikely to be much affected by physical treatment, and by the method of payment during absence. The importance of the financial incentive was recently emphasized by Buzzard and Shaw (1952), and our own data show that among patients not admitted to hospital the mean duration of absence was 9 days longer for patients paid by the firm (67 days) than for patients whose wages ceased upon leaving work (58 days); among patients admitted to hospital the difference between the two groups was insignificant.

These considerations suggest that the case for expansion of the rehabilitation services rests upon their contribution to the welfare of patients, rather than upon their effect on the duration of absence from work. Two suggestions may be made about their organization. In the first place, it would reduce the pressure on the staff of hospital out-patient departments if general practitioners could have direct access to these services without referring patients to a consultant. Secondly, the services should be provided at the place of work wherever possible, so that patients can return to work while continuing treatment.

\section{SUMMARY}

(1) An investigation of the need for physical treatment during prolonged absence from work is based upon the experience of six large firms with $\frac{0}{\vec{D}}$ a total of 30,486 employees. The medical officers of these firms interviewed on return to work all absentees who left work because of sickness or accident between October 1, 1950, and September 30, 1951 , and who were absent for 28 or more consecutive days.

(2) Approximately one in twenty employees (in one firm one in ten) had been away for at least one month during the year, and 1.4 per cent. had been in hospital. Mean durations of absence for persons admitted and not admitted to hospital were 83 and 60 days respectively. For patients admitted to hospital mean durations of absence before admis- $\vec{\circ}$ sion, in hospital, and after discharge were 8,21 , and 54 days respectively.

(3) 8.7 per cent. of patients had received some $\frac{\rho}{\infty}$ form of physical therapy, and the medical officers $\stackrel{?}{?}$ considered that a further $7 \cdot 3$ per cent. needed $v$ treatment but had not received it. 14.5 per cent. had $\vec{i}$ been admitted to a convalescent home, and it was o thought that a further $17 \cdot 8$ per cent. might have 을 benefited from admission.

(4) Although additional facilities for physical treatment would undoubtedly contribute to the welfare of patients, the data do not suggest that they would have much effect upon the mean duration of absence.

This survey was made possible by the generous cog operation of Messrs. Birmid Industries; Cadbury Bros.; Guest, Keen, and Nettlefolds; Imperial Chemical Induistries; Rubery Owen and Co.; and Stewarts and Lloyds Ltd. We are greatly indebted to the medical $\unrhd$ officers of these firms: Drs R. Wright, R. L. Ferguson, $\overrightarrow{\vec{O}}$ W. L. Lloyd, N. G. Marr, J. A. Duncan, V. V. Brown, and A. K. Hill.

\section{REFERENCE}

Buzzard, R. B., and Shaw, W. J. (1952). Brit. J. industr. Med., 9, 282 